\title{
PENGARUH SUPLEMENTASI MINERAL NUTRIENT BLOCK (MNB) PADA PAKAN DASAR RUMPUT LAPANGAN TERHADAP PERFORMANS DAN KARKAS KELINCI JANTAN LOKAL (Lepus nigricollis)
}

\author{
KUSUMA, I. G. P. E. ${ }^{1)}$, G. A. M KRISTINA DEWI ${ }^{2)}$, DAN I M. NURIYASA ${ }^{2)}$ \\ 1) Mahasiswa Program Studi Magister Peternakan Pascasarjana Universitas Udayana \\ 2) Fakultas Peternakan Universitas Udayana, Denpasar Bali \\ e-mail: endrakusuma99@gmail.com
}

\begin{abstract}
ABSTRAK
Penelitian mengenai performans dan karkas kelinci lokal akibat suplementasi Mineral Nutrient Block (MNB) pada ransum yang berbahan dasar rumput lapangan dilakukan di Desa Dajan Peken, Kecamatan Tabanan, Kabupaten Tabanan ( $50 \mathrm{~m} \mathrm{dpl}$ ) untuk pemeliharaan dan pemotongan yang berlangsung selama 3 bulan. Rancangan yang digunakan dalam penelitian ini adalah rancangan acak kelompok, dengan lima kali ulangan. Kelinci-kelinci dialokasikan secara acak kedalam empat perlakuan, yaitu kelinci-kelinci yang mendapat perlakuan ransum kontrol adalah rumput lapangan (Ro), ransum kontrol yang disuplementasi MNB $15 \mathrm{~g} / \mathrm{ekor} / \mathrm{h}$ (R1), ransum kontrol yang disuplementasi MNB $30 \mathrm{~g} / \mathrm{ekor} / \mathrm{h}$ (R2), ransum kontrol yang disuplementasi MNB $45 \mathrm{~g} / \mathrm{ekor} / \mathrm{h}$ (R3). Ransum dan air minum diberikan secara ad_libitum. Berdasarkan hasil penelitian didapatkan bahwa variabel performans dan karkas kelinci jantan lokal yang diberikan ransum dengan disuplementasi MNB 45 g/ekor/h (R3) menunjukan hasil yang lebih tinggi dari perlakuan ransum Ro (kontrol) dan perlakuan lain.
\end{abstract}

Kata kunci: rumput lapangan, MNB, peformans, karkas

\section{EFFECT MNB SUPPLEMENTATION ON THE GRASS FIELD OF BASIC FEED PERFORMANCE AND CARCASS LOCAL MALE RABBIT (Lepus nigricollis)}

\begin{abstract}
The research of the performance and carcass local male rabbit result mineral nutrient block (MNB) supplementation on ration-based grass field carried in Dajan Peken Village, Tabanan Regency (50 masl) for maintenance and cuts that lasted for 3 months. The design used in this research is a randomized block design, with five replications. The rabbits were allocated randomly into four treatments, namely rabbits treated control ration is grass field $\left(R_{0}\right)$, control ration supplemented MNB $15 \mathrm{~g} /$ head/day $\left(R_{1}\right)$, control ration supplemented MNB $30 \mathrm{~g} /$ head/day $\left(R_{2}\right)$, control ration supplemented MNB $45 \mathrm{~g} /$ head/day $\left(R_{3}\right)$. Rations and drinking water given ad_libitum. Based on the results that the variable performance and carcass local male rabbits given MNB-supplemented rations with $45 \mathrm{~g} /$ head/day $\left(\mathrm{R}_{3}\right)$ showed a higher yield than Ro ration treatment (control) and other treatments.
\end{abstract}

Keywords: grass field, MNB, peformans, carcass

\section{PENDAHULUAN}

Pengembangan budidaya kelinci di masyarakat sudah lama dilakukan, namun jumlah peternak dan populasinya masih sangat rendah. Dilihat dari potensi, kelinci sangat potensial dikembangkan sebagai penghasil daging berkualitas dengan waktu lebih cepat dibandingkan dengan ruminansia besar (sapi). Modal usaha lebih kecil dan lahan yang diperlukan juga tidak seluas yang diperlukan ternak ruminansia. Target swasembada protein hewani masyarakat
Indonesia tahun 2014 akan mengalami kendala cukup berarti bila hanya mengandalkan produksi daging dari ternak ruminansia besar. Schiere (1999) menyatakan bahwa pengembangan peternakan kelinci memberi peluang cukup besar dalam memenuhi kebutuhan gizi masyarakat karena ternak kelinci memiliki beberapa kelebihan di antaranya: (1) menghasilkan daging berkualitas tinggi, (2) dapat memanfaatkan limbah pertanian dan limbah dapur sebagai bahan pakan, (3) selain produk utama berupa daging, hasil sampingannya (kulit beserta bulu, kepala, kaki, ekor, urin serta feses 
dapat digunakan untuk berbagai keperluan.

Fakta yang ada di lapangan, kebanyakan peternak hanya memberikan rumput lapangan saja, dan sebagian kecil peternak memberikan suplementasi konsentrat berupa ampas tahu, dedak atau campuran ampas tahu dengan dedak. Peternak tidak pernah menakar dan menghitung kandungan nutrient yang ada pada konsentrat. Kondisi ini sering menyebabkan kerugian pada peternak karena kelinci banyak mengalami mortalitas (Nuriyasa, 2016). Salah satu kelemahan peternak sampai saat ini adalah pengetahuan tentang kualitas ransum sangat rendah terutama pemahaman protein, energi dan mineral Suttle (2010). Mineral merupakan nutrien yang diperlukan dalam jumlah sedikit namun mempunyai peranan penting dalam metabolism ternak. Mineral berperanan dalam hal: (1) sebagai pembentukan organ tubuh, (2) fungsi fisiologis, (3) fungsi katalisator enzim dan (4) berperanan dalam replikasi dan pemecahan sel. Peternak memberikan ransum yang sama pada semua status fisiologi ternak. Kuantitas dan kualitas ransum tidak pernah menjadi pertimbangan oleh peternak dan diberikan seadanya. Pemeliharaan kelinci seperti ini sering menjadi keluhan oleh peternak karena banyak anak kelinci mati atau induk bersifat kanibalisme. Xiccato et al. (1999) menyatakan keseimbangan nutrient dalam ransum sangat menentukan produktivitas ternak kelinci. Menurut de Blass dan Wiseman (1998) protein, karbohidrat, lemak, mineral, vitamin dan air merupakan nutrien yang sangat diperlukan oleh ternak kelinci. Hasil penelitian Salma (2004) mendapatkan bahwa persentase kebuntingan kelinci yang diberi ransum dengan kandungan protein 21\% lebih tinggi daripada $16,64 \%$ dan $13,17 \%$ masing-masing $100 \%$, $60 \%$ dan $49 \%$. Lama bunting tidak dipengaruhi oleh kandungan protein ransum namun jumlah kelahiran dan berat lahir lebih tinggi pada kelinci yang diberi ransum dengan kandungan protein 21\% dan 16,64\% dibandingkan dengan kandungan protein $13,17 \%$.

Penelitian ini untuk mengetahui meningkatkan performans dan karkas kelinci lokal akibat suplementasi Mineral Nutrient Block (MNB) pada ransum yang berbahan dasar rumput lapangan.

\section{MATERI DAN METODE}

\section{Kelinci}

Kelinci yang digunakan dalam penelitian ini adalah kelinci jantan lokal (Lepus nigricollis) dengan bobot badan awal rata-rata $600,0 \pm 96,5$ gr yang dilakukan di Desa Dajan Peken, Kecamatan Tabanan, Kabupaten Tabanan (50 mdpl) untuk pemeliharaan dan pemotongan yang berlangsung selama 3 bulan.

\section{Kandang}

Penelitian menggunakan 20 petak kandang battery dengan ukuran masing-masing panjang $70 \mathrm{~cm}$, lebar 50 $\mathrm{cm}$ dan tinggi $45 \mathrm{~cm}$ (Sceire, 1999). Ketinggian petak kandang diukur dari lantai bangunan kandang adalah $70 \mathrm{~cm}$. Masing-masing petak kandang dilengkapi dengan tempat makanan dan tempat air minum yang terbuat dari tempurung kelapa.

\section{Variabel yang Diamati}

Variabel peformans yang diamati dalam penelitian ini meliputi: bobot badan akhir, pertambahan bobot badan harian, konsumsi ransum dan konversi ransum. Bobot badan akhir didapatkan dari penimbangan bobot kelinci pada akhir penelitian.

Data karkas diperoleh dengan cara memotong ternak kelinci pada akhir penelitian. Pemotongan ternak kelinci dengan memotong vena jugularis pada leher untuk mengeluarkan darahnya (Alhaidary et al., 2010). Persentase karkas dihitung sebagai berat karkas segar dibagi dengan berat tubuh sebelum dipotong dikalikan 100 (Lukefahr et al., 1981). Untuk mengetahui komposisi fisik karkas maka dilakukan pemisahan antara daging, tulang dan lemak. Rasio daging dengan tulang didapat dengan membagi berat daging dengan tulang.

\section{Metode}

Penelitian lapangan dilaksanakan dengan menggunakan rangcangan acak kelompok (RAK) dengan lima kali ulangan. Ransum kontrol adalah rumput lapangan (Ro), ransum kontrol yang disuplementasi MNB $15 \mathrm{~g} /$ ekor/h (R1), ransum kontrol yang disuplementasi MNB $30 \mathrm{~g} /$ ekor/h (R2), ransum kontrol yang disuplementasi MNB $45 \mathrm{~g} / \mathrm{ekor} / \mathrm{h}$ (R3). Nutrien dicetak dalam bentuk balok dengan ukuran panjang $5 \mathrm{~cm}$, lebar $3 \mathrm{~cm}$ dan tinggi $3 \mathrm{~cm}$

\section{Analisis Statistik}

Data yang diproleh dianalisis dengan analisis ragam, apabila diantara perlakuan terdapat perbedaan yang nyata $(\mathrm{P}<0,05)$ maka analisis dilanjutkan dengan uji jarak berganda Duncan (Steel dan Torrie, 1980). Data mortalitas ditransformasi terlebih dahulu sebelum dianalisis dengan tehnik transformasi logaritmik yaitu: $\log (\mathrm{x}+1)$.

\section{HASIL DAN PEMBAHASAN}

Data hasil penelitian pengaruh suplemantasi MNB dengan aras berbeda pada pakan kelinci berbasis rumput lapangan terhadap performans kelinci lokal disajikan pada Tabel 1. Kelinci yang diberi ransum R3 menghasilkan bobot badan akhir paling tinggi yaitu 1.991,8 g, sedangkan kelinci yang diberi ransum R2, R1 
dan Ro masing-masing 20,03\%, 25,59\%, dan 36,46\% lebih rendah $(\mathrm{P}<0,05)$, seperti pada Tabel 1. Kelinci yang diberi ransum $\mathrm{R}_{3}$ mengasilkan bobot badan akhir paling tinggi dibandingkan dengan perlakuan lainnya disebabkan karena konsumsi ransum pada pada perlakuan R3 paling tinggi $(58,37 \mathrm{~g} / \mathrm{hr})$ dibandingkan dengan R2 (56,21 g/hr), R1 (54,58 g/hr) dan Ro (46,74 g/ hr). Tillman et al. (1986) menyatakan konsumsi ransum yang lebih tinggi menyebabkan konsumsi nutrien juga lebih tinggi sehingga lebih banyak energi dan protein yang bisa dipergunakan untuk pertumbuhan. Nuriyasa et al. (2012) menyatakan kelebihan energi setelah kebutuhan hidup pokok terpenuhi maka kelebihan energi tersebut akan dipergunakan untuk pertumbuhan.

Tabel 1. Performans kelinci lokal yang diberi pakan dasar rumput lapangan dengan aras suplementasi mnb berbeda

\begin{tabular}{|c|c|c|c|c|c|}
\hline \multirow{2}{*}{ Variabel } & \multicolumn{4}{|c|}{ Perlakuan } & \multirow{2}{*}{$\mathrm{SEM}^{3}$} \\
\hline & $\mathrm{RO}^{1)}$ & R1 & $\mathrm{R} 2$ & R3 & \\
\hline $\begin{array}{l}\text { Bobot badan Akhir } \\
\text { (g) }\end{array}$ & $1.265,4^{d}$ & $1.482,0^{c}$ & $1.592,8^{b}$ & $1.991,8^{a}$ & 17,5 \\
\hline $\begin{array}{l}\text { Pertambahan Bobot } \\
\text { Badan }(\mathrm{g} / \mathrm{hr})\end{array}$ & $7,82^{b}$ & $9,37^{\mathrm{ab}}$ & $11,46^{b}$ & $15,81^{\mathrm{a}}$ & 0,35 \\
\hline $\begin{array}{l}\text { Konsumsi Ransum } \\
\text { (g/hr) }\end{array}$ & $45,14^{d}$ & $55,22^{\mathrm{C}}$ & $59,60^{b}$ & $59,74^{a}$ & 0,08 \\
\hline Konversi Ransum & $5,77^{\mathrm{a}}$ & $5,89^{a}$ & $5,20^{b}$ & $3,77^{c}$ & 0,09 \\
\hline $\begin{array}{l}\text { Konsumsi Air } \\
(\mathrm{ml} / \mathrm{hr})\end{array}$ & $105,22^{\mathrm{C}}$ & $111,52^{b c}$ & $119,49^{b}$ & $133,69^{a}$ & 1,32 \\
\hline
\end{tabular}

Keterangan:

1) RO: Ramsum rumput lapangan tanpa suplementasi MNB

R1: Ransum rumput lapangan dengan suplementasi MNB $15 \mathrm{~g} / \mathrm{hr}$

R2: Ransum rumput lapangan dengan suplementasi MNB $30 \mathrm{~g} / \mathrm{hr}$

R3: Ransum rumput lapangan dengan suplementasi MNB $45 \mathrm{~g} / \mathrm{hr}$

2) Superskrip yang sama pada baris yang sama menunjukkan perbedaan tidak nyata $(P>0,05)$ dan superskrip berbeda pada baris yang sama menunjukkan perbedaan nyata $(P<0,05)$

3) SEM: Standard Error of the Treatment Means

Pada Tabel 1 menunjukan bahwa pertambahan bobot badan paling tinggi dihasilkan oleh kelinci yang diberi perlakuan ransum $\mathrm{R}_{3}$ yaitu 15,81g/hr, sedangkan pertambahan bobot badan kelinci yang diberi perlakuan R2, R1 dan Ro masing-masing 27,51\%, 40,73\% dan $50,53 \%$ lebih rendah $(\mathrm{P}<0,05)$. Hal ini disebabkan karena konsumsi ransum kelinci yang diberi ransum R3 paling tinggi dan konversi ransum paling rendah yang artinya efisiensi penggunaan ransum paling tinggi. Kondisi ini juga didukung oleh data koefisien cerna bahan kering ransum, efisiensi perubahan GE menjadi DE dan koefisien cerna protein kelinci yang diberi ransum R3 pailing tinggi yaitu secara berurutan sebesar $75,43 \%, 76,03 \%$ dan 78,11\%. Hasil penelitian Lubis (1992) melaporkan kandungan serat kasar yang tinggi dalam ransum berpengaruh tehadap daya cerna yang lebih rendah.

Kelinci yang diberi ransum Ro mengkonsumsi ransum paling rendah yaitu $45,14 \mathrm{~g} / \mathrm{hr}$. Kelinci yang diberi perlakuan ransum R1, R2 dan R3 mengkonsumsi ransum 22,33\%, 32,03\% dan 32,34\% lebih tinggi dibandingkan dengan Ro yang secara statistik berbeda nyata $(\mathrm{P}<0,05)$, seperti pada Tabel 1 . Konsumsi rasum paling rendah terjadi pada kelinci yang diberikan ransum Ro disebabkan karena rumput lapangan mengandung serat kasar tinggi sehingga kurang palatabel bagi ternak kelinci. Dilihat dari data kecernaan bahan kering, ransum Ro adalah paling rendah yaitu $68,35 \%$, R1 (68,52\%), R2 (74,54\%) dan R3 (75,43\%).

Konversi ransum paling rendah terjadi pada kelinci yang diberikan ransum $\mathrm{R}_{3}$ yaitu 3,77. Konversi ransum kelinci yang diberikan ransum R2, R1 dan Ro masingmasing 37,93\%, 56,23\% dan 53.05\% lebih tinggi $(\mathrm{P}<0,05)$. Perlakuan R1 menghasilkan konversi ransum 5,89 sedangkan perlakuan ransum Ro menghasilkan konversi ransum 2.08 \% lebih rendah dibandinkan R1 namun secara statistik tidak berbeda nyata $(\mathrm{P}>0,05)$, seperti pada Tabel 1. Hal ini disebabkan karena pertambahan berat badan kelinci yang diberi ransum $\mathrm{R}_{3}$ paling tinggi dan secara kuantitatif konsumsi ransum tidak jauh berbeda. Data juga menunjukan bahwa koefisien cerna bahan kering, efisiensi perubahan GE menjadi DE serta koefisien kecernaan protein pada kelinci yang diberi ransum Ro paling rendah yaitu secara berurutan sebesar 68,35\%, 70,92\% dan 70,79\% dibandingkan dengan perlakuan lain.

Kelinci yang diberi ransum $\mathrm{R} 3$ mengkonsumsi air paling tinggi yaitu $133,69 \mathrm{ml} / \mathrm{hr}$, sedangkan konsumsi air pada perlakuan ransum R2, R1 dan Ro masingmasing 10,62\%, 16,58\% dan 21,29\% lebih rendah $(\mathrm{P}<0,05)$ daripada perlakuan $\mathrm{R}_{3}$ (Tabel 1). Kelinci yang diberikan ransum $\mathrm{R}_{3}$ mengkonsumsi air paling tinggi, hal ini disebabkan karena konsumsi ransum pada kelinci yang diberikan ransum R3 paling tinngi. Mc.Nitt et al. (1996) menyatakan konsumsi air pada ternak kelinci diperlukan untuk memperlancar proses pencernaan dan metabolisme yang terjadi pada tubuh kelinci. Nuriyasa et al. (2016) menyatakan bahwa pertumbuhan kelinci yang lebih tinggi juga memerlukan konsumsi air yang lebih tinggi terutama pada ternak kelinci yang diberikan pakan pellet karena air diperlukan untuk melunakkan pakan sebelum dicerna.

Kelinci yang diberi perlakuan $\mathrm{R}_{3}$ menghasilkan bobot potong paling tinggi yaitu $1.932 \mathrm{~g}$, sedangkan kelinci yang diberi perlakuan R2, R1 dan Ro masingmasing 220,23\%, 28,31\% dan 35,61\% lebih rendah ( $\mathrm{P}<0,05)$ dibandingkan dengan perlakuan $\mathrm{R}_{3}$ (Tabel 2). Bobot potong lebih tinggi pada kelinci yang mendapat ransum R3 disebabkan kelinci yang diberi perlakuan R3 mengkonsumsi ransum paling tinggi sehingga konsumsi energi dan protein sebagai komponen pembentuk jaringan tubuh juga paling tinggi (Tabel 1), sesuai dengan pendapat Nuriyasa Nuriyasa (2012). Data pada Tabel 1 juga menunjukan bahwa efisiensi penggunaan 
Tabel 2. Karkas kelinci lokal yang diberi pakan dasar rumput lapangan dengan aras suplementasi mnb berbeda

\begin{tabular}{|c|c|c|c|c|c|}
\hline \multirow{2}{*}{ Variabel } & \multicolumn{4}{|c|}{ Perlakuan } & \multirow{2}{*}{$\mathrm{SEM}^{3)}$} \\
\hline & $\mathrm{RO} 0^{1)}$ & R1 & R2 & R3 & \\
\hline Bobot potong (g) & $1244,6^{\mathrm{c} 2)}$ & $1385^{b c}$ & $1541,2^{b}$ & $1932^{\mathrm{a}}$ & 25,61 \\
\hline Bobot karkas (g) & $576,6^{c}$ & $618,8^{c}$ & $730,2^{b}$ & $944,8^{a}$ & 16,30 \\
\hline Persentase karkas(\%) & $46,13^{a}$ & $44,66^{a}$ & $47,40^{\mathrm{a}}$ & $48,88^{a}$ & 0,75 \\
\hline Panjang karkas (cm) & $31,6^{b}$ & $32,1^{b}$ & $32,4^{b}$ & $34,6^{a}$ & 0,19 \\
\hline \multicolumn{6}{|c|}{ Komposisi Fisik Karkas } \\
\hline Daging (g/100g karkas) & $59,82^{\mathrm{a}}$ & $59,32^{\mathrm{a}}$ & $67,74^{\mathrm{a}}$ & $65,92^{\mathrm{a}}$ & 0,38 \\
\hline Tulang (g/100g karkas) & $37,32 a$ & $37,68^{a}$ & $29,24^{b}$ & $31,08^{b}$ & 0,36 \\
\hline Lemak (g/100g karkas) & $2,86^{\mathrm{a}}$ & $3,0^{\mathrm{a}}$ & $3,16^{\mathrm{a}}$ & $2,98^{\mathrm{a}}$ & 0,14 \\
\hline
\end{tabular}

Keterangan:

1) RO: Ramsum rumput lapangan tanpa suplementasi MNB

R1: Ransum rumput lapangan dengan suplementasi MNB $15 \mathrm{~g} / \mathrm{hr}$

R2: Ransum rumput lapangan dengan suplementasi MNB $30 \mathrm{~g} / \mathrm{hr}$

R3: Ransum rumput lapangan dengan suplementasi MNB $45 \mathrm{~g} / \mathrm{hr}$

2) Superskrip yang sama pada baris yang sama menunjukkan perbedaan tidak nyata $(P>0,05)$ dan superskrip berbeda pada baris yang sama menunjukkan perbedaan nyata $(\mathrm{P}<0,05)$

3) SEM: Standard Error of the Treatment Means

ransum pada kelinci yang diberi ransum R3 paling tinggi sehingga pertumbuhan dan bobot karkas yang dihasilkan juga lebih tinggi, sesuai dengan pendapat de Blass dan Wiseman (1997).

Bobot karkas kelinci paling tinggi dihasilkan oleh perlakuan R3 yaitu 944,8g. Perlakuan ransum R2, R1 dan Ro masing-masing menghasilkan bobot karkas 22,71\%, 34,50\% dan 38,97\% lebih rendah yang secara setatistik berbeda nyata $(\mathrm{P}<0,05)$ seperti pada Tabel 5 . Perlakuan ransum R3 menghasilkan bobot karkas lebih tinggi daripada perlakuan R2, R1 dan Ro. Kelinci yang mendapat perlakuan ransum $\mathrm{R} 3$ menghasilkan bobot karkas paling tinggi dibandingkan dengan R2, R1 dan Ro. Kelinci yang diberi ransum R3 mengkonsumsi energi dan protein paling tinggi yaitu secara berurutan sebesar 254,89 K.kal/hari dan 6,75g/hari. Energi dan protein merupakan komponen utama penyusun jaringan tubuh (Tillman et al, 1986). Konsumsi energi dan protein yang tinggi pada kelinci dengan perlakuan ransum $\mathrm{R}_{3}$ mengakibatkan pertumbuhannya paling tinggi yang diindikasikan oleh bobot badan akhir yang dihasilkan paling tinggi. Pendapat yang sama dikemukakan oleh Kartadisastra (2011), McNitt et al. (1996), de Blas dan Wiseman (1998) yaitu kualitas ransum berpengaruh terhadap bobot karkas yang dihasilkan.

Tidak terjadi perbedaan yang nyata $(\mathrm{P}>0,05)$ terhadap variable persentase karkas kelinci pada perlakuan ransum yang berbeda (Tabel 2). Persentase karkas yang tidak berbeda ini disebabkan karena kelinci yang menghasilkan bobot potong lebih tinggi juga menghasilkan bobot non karkas lebih tinggi sehingga tidak berpengaruh pada persentase karkas yang dihasilkan, sesuai dengan pendapat Kartadisastra (2011) dan Puger (1993).

Perlakuan ransum Ro menghasilkan panjang karkas paling rendah yaitu $31,6 \mathrm{~cm}$. Perlakuan ransum
R1 dan R2 dan masing-masing menghasilkan panjang karkas 1,58\%, 2,5\% lebih tinggi namun secara statistik tidak berbeda nyata $(\mathrm{P}>0,05)$. Perlakuan ransum R3 menhasilkan karkas 9,5\% lebih panjang daripada perlakuan laian yang secara statistik berbeda nyata $(\mathrm{P}<0,05)$, seperti pada Tabel 2. Hal ini disebabkan karena kelinci yang diberikan ransum $\mathrm{R}_{3}$ mengkonsumsi MNB paling tinggi sehingga konsumsi mineral Ca dan P sebagai komponen utama pembentuk kerangka tubuh sehingga menyebabkan panjang karkas yang dihasilkan juga paling tinggi.

Berat daging karkas kelinci yang diberikan ransum R2 adalah 67,74g/10og karkas, sedangkan berat daging karkas kelinci yang diberi perlakuan ransum R3, Ro dan R1 masing-masing 2,69\%, 11,69\% dan 12,42\% lebih rendah daripada R2 namun secara statistik tidak berbeda nyata $(\mathrm{P}>0,05)$, seperti pada Tabel 2. Hal ini disebabkan karena konsumsi energi dan protein sebagai komponen utama penyusun jaringan daging pada $\mathrm{R}_{3}$ lebih tinggi daripada perlakuan lain. Pendapat ini didukung pula oleh Praga (1998) menyatakan protein tubuh ternak tersuusun dari asam-asam amino dengan ikatan peptida dan membentuk ikatan polipeptida.

Berat tulang kelinci yang diberikan ransum R1 adalah 37,68g/10og karkas, sedangkan berat tulang kelinci yang diberikan ransum Ro adalah $0,95 \%$ lebih rendah secara statistik tidak berbeda nyata $(\mathrm{P}>0,05)$. Berat tulang kelinci yang diberi ransum R3 dan R2 masing-masing $17,51 \%$ dan $22,39 \%$ lebih rendah $(\mathrm{P}<0,05)$ daripada R1, seperti pada Tabel 2. Hal ini disebabkan karena kelinci yang tidak mendapat suplementasi MNB sebagai sumber mineral Ca dan P pada perlakuan control (Ro) menyebabkan proses pembentukan kerangka tubuh tidak sempurna, sesuai dengan pendapat Suttle (2010).

Kelinci yang diberikan ransum R2 menghasilkan berat lemak 3,16g/100g karkas, sedangkan kelinci yang diberikan ransum R3, R1 dan Ro masing-masing 5,06\%, 5,69\% dan 9,49\% lebih rendah daripada R2 namun secara statistik tidak berbeda nyata $(\mathrm{P}>0,05)$, seperti pada Tabel 2. Tidak terjadi perbedaan terhadap persentase lemak yang dihasilkan, mengindikasikan bahwa tidak terjadi perbedaan dalam penyimpanan kelebihan energi yang dikonsumsi. Pendapat ini sesuai dengan McNitt et al. (1996) yang menyatakan ternak mengkonsumsi energi untuk memenuhi kebutuhan hidup pokok terlebih dahulu baru untuk pertumbuhan dan terakhir kelebihan energi yang dikonsumsi akan disimpan dalam bentuk lemak tubuh. Secara kuantitatif persentase lemak dihasilkan oleh kelinci yang diberikan ransum Ro paling rendah dibandingkan dengan R1, R2 dan R3. Kondisi ini berkaitan dengan jumlah energi yang dikonsumsi oleh ternak kelinci. Haresign et al. (1977) dan Tillman et al. (1986) yang menyatakan bahwa ternak mengkonsumsi ransum dengan tujuan untuk 
memenuhi kebutuhan energinya dan kelebihan energi yang dikonsumsi akan disimpan dalam bentuk lemak. Makin tinggi konsumsi energi maka jumlah energi yang dapat disimpan sebagai lemak semakin tinggi.

\section{SIMPULAN}

Berdasarkan hasil penelitian diatas maka dapat disimpulkan bahwa perlakuan ransum pakan dasar rumput lapangan dengan suplementasi MNB $45 \mathrm{~g} /$ ekor/hari lebih tinggi dari pada perlakuan lain terhadap variabel performans dan karkas yang diamati.

\section{UCAPAN TERIMAKASIH}

Pada kesempatan ini kami mengucapkan banyak terimakasih kepada Rektor Universitas Udayana, Direktur Program Pasca Sarjana Universitas Udayana, Ketua Progran Studi Ilmu Peternakan Program Pasca Sarjana Universitas Uadayana dan Dekan Fakultas Peternakan Universitas Udayana atas pelayanan administrasi dan fasilitas pendidikan yang diberikan kepada penulis selama menjalani perkulihaan.

\section{DAFTAR PUSTAKA}

Alhaidary, A., H. E. Mohamed and A. C. Beynen. 2010. Impact of dietary fat type and amount on growth performance and serum cholesterol in Rabbits. American J. of Animal and Veterinary Sciences 5(1): 60-64.

De Blass, C and J. Wiseman. 1998. The Nutrition of the Rabbit. CABI Publishinr. University of Nottingham. Nottingham. P.39-55.

Haresign, W., H. Swan, D. Lewis. 1977. Nutrition and the Climatic Environment. Faculty of Agricultural Sciences, University of Nottingham, London.

Kartadisatra, H.R. 2011. Kelinci Unggul. Penerbit Kanisius, Jakarta.

Lukefahr, S.D., W.D. Hohenboken, P.R. Cheeke, N.M. Patton and W.H. Kennick. 1981. Carcass and meat characteristics of plemish giant and new zealand white purebreed and terminal - crossbred Rabbits. J. Of Appl, Res. 4(3): 66-72.
Mc.Nitt, J.I., N.M. Nephi, S.D. Lukefahr and P.R. Cheeke. 1996. Rabbit Production. Interstate Publishers, Inc.p. 78-109.

Nuriyasa, I. M. 2016. Beternak kelinci lokal di dataran rendah tropis. majalah nandaka. peluang bisnis dan ternak upakara. Fakultas Peternakan. Universitas Udayana: Denpasar. Hal. 35-37.

Nuriyasa, M. 2012. Respon Biologi Serta Pendugaan Kebutuhan Energi dan Protein Ternak Kelinci Kondisi Lingkungan berbeda Di Daerah Dataran Rendah Tropis. Disertasi. Program Pasca Sarjana. Universitas Udayana. Denpasar.

Praga, M.J. 1998. Protein Requirement. In. The Nutrition of the Rabbit. Ed. C. de Blas and J.Wiseman. CABI Publishing, New York. p.133-143.

Puger, A.W. 1993. Evaluasi Hijauan Provenance Gamal (Gliricidia sepium) terhadap Pertumbuhan dan Komposisi Karkas Kelinci. Tesis. Program Pascasarjana, Institut Pertanian Bogor.

Salma, U., A.G. Miah, Y. Akter, Z.H. Khandaker and A.Reza. 2004. Effect of Different Of Protein Suplementation On Reproductive Performance Of Rabbit Does Under Tropical Condition. International Journal of Agriculture \& Biology. http://www.fspublishers.org/ijab/ past-issues/IJAB vol.6 No.5/12. Disitir Tanggal 20 Nopember 2010.

Schiere, J.B. 1999. Backyard Farming in the Tropics. CTA Pubblished, New York.

Steel, R.G.D. and J.H. Torrie. 1980. Prinsip dan Prosedur Statistika. Suatu Pendekatan Biometrik. Edisi kedua. Diterjemahkan Oleh Sumantri. Gramedia. Jakarta.

Tillman, A.D., H. Hartadi, S . Reksohardiprodja.,P.Soeharto dan L. Soekamto. 1986. Ilmu Makanan Ternak Dasar. Gadjah Mada, University Press, Yogyakarta.

Xiccato, G. M.Bernardini, C.Castellini, A. Dalle Zotte, P.I. Queaque and A.Trocino.1999. Effect of postweaning feeding on the performance and energy balance of famale rabbits at different physiological states. Journal of Animal Science, Vol. 77 (2) : 416-426. http://jas.fas org/cgi/content/abstract/77/2/416. Disitir Tanggal 20 Nopember 201. 